\title{
Incidental finding of ovarian teratoma on post-therapy scan for papillary thyroid cancer and impact of SPECT/CT imaging
}

\author{
Achado incidental de teratoma ovariano em uma avaliação \\ pós-tratamento para carcinoma papilar de tiroide e impacto \\ da tomografia computadorizada por emissão de fóton único
}

1 Department of Medicine, King Saud University, Riyadh, Saudi Arabia

2 Department of Nuclear Medicine, University of Western Ontario, Canada

Correspondence to: Anwar Ali Jammah Department of Medicine, King Saud University, Riyadh, Saud Arabia

P. O. Box 2925 Riyadh 11461 Kingdom of Saudi Arabia dranwarjammah@hotmail.com

Received on Aug/25/2011 Accepted on Nov/1/2011
Anwar Ali Jammah', Albert Driedger², Irina Rachinsky²

\section{SUMMARY}

A 41-year old woman post thyroidectomy and neck dissection is presented in this case. She initially presented goiter and an enlarged cervical lymph node. She had no family history of cancer or radiation therapy. She had total thyroidectomy and found to have papillary thyroid cancer (T4N1M0). Histopathology report revealed multifocal classical papillary thyroid carcinoma with lympho-vascular invasion, extra-thyroidal extension, and positive lymph nodes. She was treated with 6.5 Gigabecquerel $(\mathrm{GBq})$ of ${ }^{131}$ lodine. Whole-body scan showed uptake in the neck and large focus in the left lower abdomen. Single-photon emission computed tomography SPECT/CT demonstrated a round shaped mass in the left pelvis. Pathology revealed cystic teratoma with benign thyroid tissue (struma ovarii), and no malignancy. Two months later, she had the second treatment with $5.5 \mathrm{GBq}{ }^{131}$ lodine. Her follow-up stimulated and non-stimulated thyroglobulin levels were significantly lower, and there was no abnormal uptake in the follow-up scan. Arq Bras Endocrinol Metab. 2011;55(7):490-3

\section{SUMÁRI0}

Este é o caso de uma mulher de 41 anos de idade, com pós-tireoidectomia e dissecção da área do pescoço. Ela inicialmente apresentou bócio e um linfonodo cervical aumentado. Não tinha histórico familiar de câncer ou tratamento com radiação. Ela foi submetida a uma tiroidectomia total e se observou um carcinoma papilar de tiroide (T4N1M0). Os achados histopatológicos revelaram carcinoma papilar multifocal clássico com invasão linfovascular, extensão extratiroideana e linfonodos positivos. Ela foi tratada com 6.5 Gigabecquerel (GBq) de lodo ${ }^{131}$. A tomografia de corpo inteiro mostrou captação na área do pescoço e um grande foco no abdômen inferior esquerdo. A tomografia computadorizada por emissão de fóton único SPECT/CT demonstrou uma massa arredondada na pelve esquerda. A análise patológica revelou um teratoma cístico com tecido tiroideano benigno (struma ovarii) e nenhuma malignidade. Dois meses depois, ela foi submetida a um segundo tratamento com $5.5 \mathrm{GBq}$ de lodo ${ }^{131} .0$ acompanhamento dos níveis de tireoglobulina estimulada e não estimulada foi significativamente mais baixo e não houve captação anormal na tomografia seguinte. Arq Bras Endocrinol Metab. 2011;55(7):490-3

\section{INTRODUCTION}

$\mathrm{W}$ e report a rare case of benign struma ovarii discovered in the total body scan after radioactive iodine treatment for papillary thyroid carcinoma. We found only anecdotal reports describing the incidental finding of struma ovarii found on post radioiodine ablation scan for treatment of thyroid cancer. We include interesting images of the whole-body scan and single-photon emission computed tomography (SPECT/CT) of this case.

SPECT produces computer-generated images of local radiotracer uptake, while CT produces 3-D anatomic images of X-ray density. Combined SPECT/CT 
imaging provides sequentially functional information from SPECT, and anatomic information from CT, in a single examination.

Morphological and functional imaging modalities are complementary in the diagnosis of functional tumors, such as thyroid cancer. SPECT/CT improves the diagnostic sensitivity and specificity by precisely localizing areas of abnormal and/or physiological tracer uptake. Moreover, it can aid in achieving accurate dosimetric estimates, as well as in guiding interventional procedures.

\section{MATERIAL AND METHOD}

Thyroglobulin levels were measured by radioimmunoassay (RIA), and antithyroglubulin antibodies were measured by chemiluminescent immunoassay (ICMA). For SPECT/CT, we used a GE Infinia Hawkeye camera.

The rhTSH (Thyrogen)-stimulation protocol was applied when treating our patient with ${ }^{131}$ Iodine. The patient was asked to follow a low iodine diet for 12 days. After 10 days of this diet, two intramuscular injections of $0.9 \mathrm{mg}$ of rhTSH were given on two consecutive days. She was given a therapeutic dose of iodine on day 3. On day five, a venous blood sample was collected for thyroid stimulating hormone (TSH), thyroglobulin and antithyroglobulin. On day 5, Whole Body Scan (WBS) and SPECT/CT were carried out.

The follow-up of the patient with thyroid cancer includes a blood test for TSH, Free thyroxine (T4), Thyroglobulin level, and antithyroglubulin antibodies every 6 to 12 months. Stimulated thyroglobulin and antithyroglobulin antibodies will be carried out as indicated, at least to ensure that thyroglobulin does not increase again. WBS and SPECT/CT are not used routinely in the follow-up of low risk cases.

\section{CASE}

A 41-year old woman was initially seen in the surgical clinic for goiter and a mass on the left side of her neck. She was clinically euthyroid and had no family history of thyroid cancer or exposure to ionizing radiation. Her thyroid stimulating hormone (TSH) level was 3.3 $\mathrm{mIU} / \mathrm{L}$ (normal $=0.25-5 \mathrm{mIU} / \mathrm{L}$ ). Thyroid ultrasound showed multinodular goiter with a left dominant thyroid nodule measuring $1.8 \times 1.6 \times 1.6 \mathrm{~cm}$, and left-sided lymph node measuring $4.2 \times 2.5 \times 3 \mathrm{~cm}$. Fine needle aspirations of the thyroid nodule and cervical lymph node were done, and cytology result was suspicious for papillary thyroid carcinoma (PTC) of the thyroid nodule, with metastasis to the cervical lymph node.

She underwent total thyroidectomy with central and a left modified neck dissection two months later. Histopathology confirmed the diagnosis of multifocal classical type of PTC involving both lobes and isthmus, with lymphatic invasion and extra-thyroidal extension. Four out of the 25 removed lymph nodes were found to contain metastatic disease; the largest lymph node measured $4.5 \mathrm{~cm}$.

Two months after surgery, her thyroglobulin was $280 \mathrm{mg} / \mathrm{L}$, and antithyroglobulin antibodies were undetectable. After 10 days on a low iodine diet and rhTSH (Thyrogen)-stimulation protocol, she was treated with oral ${ }^{131}$ Iodine (6.5 GBq). Five days after the treatment, whole-body scan (WBS) showed mild uptake in the neck, representing thyroid remnants, and a large focus in the left lower abdomen (Figure 1). Abdominal SPECT/CT, which was part of the WBS, demonstrated a three-centimeter, round, soft-tissue mass in the left pelvis (Figure 2), most likely representing functioning benign or malignant thyroid tissue. The stimulated thyroglobulin level on day five after Thyrogen injection was $2,315 \mu \mathrm{g} / \mathrm{L}($ normal $<1 \mu \mathrm{g} / \mathrm{L})$.

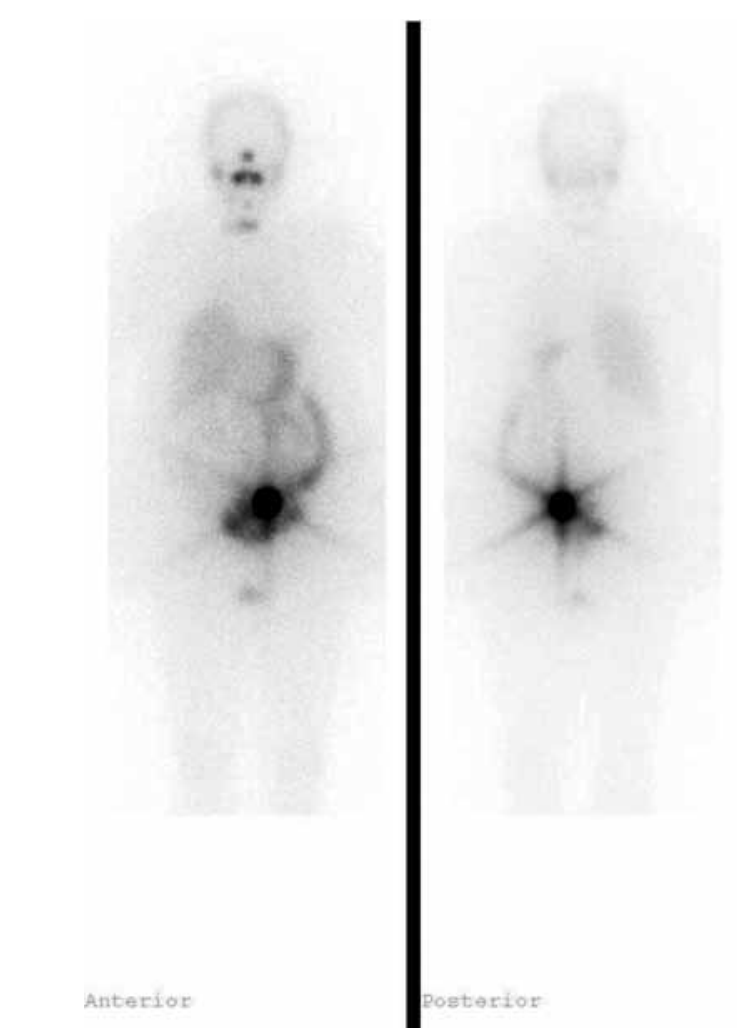

Figure 1. Post-therapy (131 I) whole-body scan demonstrated: (Right) Anterior image: physiological uptake in the nose and mouth; activity in thyroid remnant in the thyroid bed, and minimal uptake in the liver. (Left and Right) Anterior and Posterior image: prominent uptake in the left lower abdomen/pelvis; and physiological uptake in the bladder. 


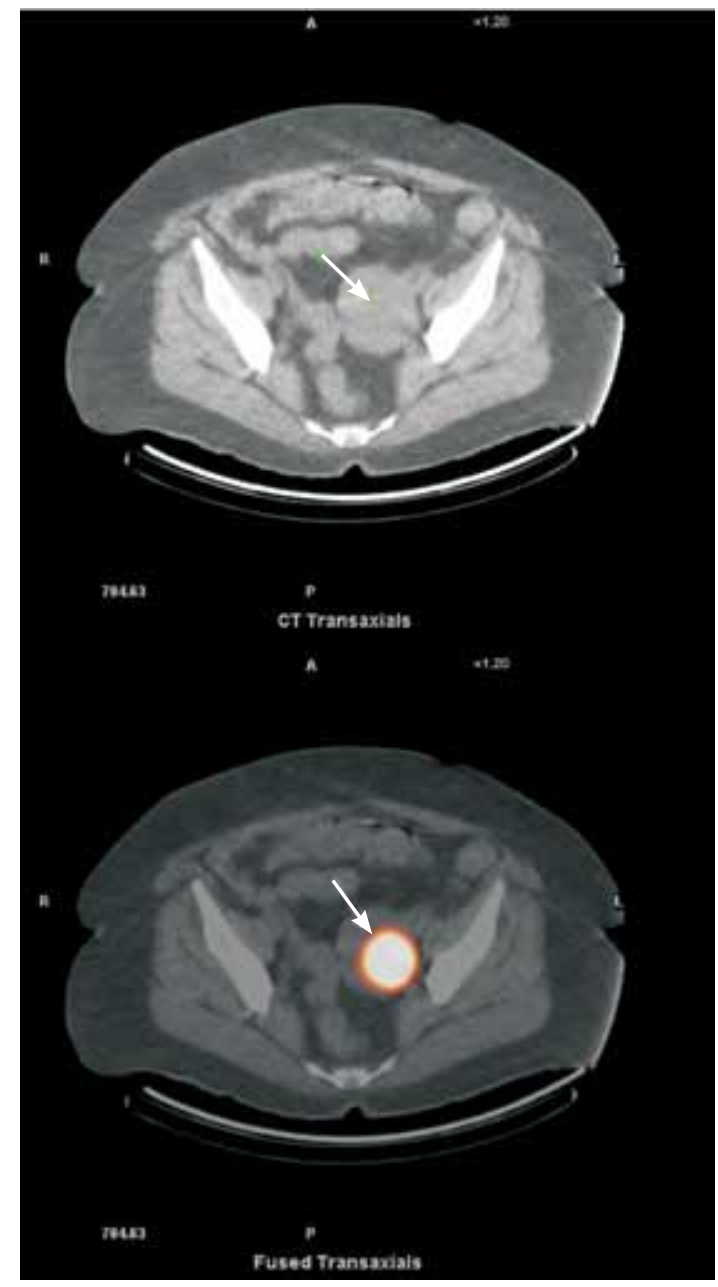

Figure 2. ${ }^{131}$ I-SPECT/CT provided metabolic and anatomic information that the foci of ${ }^{131}$ I WBS was localized in the left pelvis. Three-centimeter, round, soft-tissue mass (arrows) which most likely represented functioning thyroid tissue compatible with ovarian tumor.

Two months later, she underwent laparotomy for bilateral salpingo-oophorectomy. Histopathology confirmed a left mature cystic teratoma with benign thyroid tissue (struma ovarii), measuring $3.3 \times 3.1 \times 2.1 \mathrm{~cm}$, with no cytological or architectural changes suggestive of malignancy.

The patient's suppressed thyroglobulin fell from 280 at baseline to $3.7 \mu \mathrm{g} / \mathrm{L}$ six months after ablation. Eight months after the radioactive iodine ablation and six months after salpingo-oophorectomy, she received a second treatment of radioactive iodine ablation with 5.5 GBq, after stimulation with rhTSH. The post-ablation WBC showed a small residual focus of radioiodine uptake in the right neck close to the midline, and no abdominal uptake. Stimulated thyroglobulin fell significantly from $2,315 \mu \mathrm{g} / \mathrm{L}$ at the first therapy, to 9.4 $\mu \mathrm{g} / \mathrm{L}$ at the second therapy.
She is currently on $0.125 \mathrm{mg}$ of levothyroxine, with appropriate TSH suppression.

\section{DISCUSSION}

Ovarian radioiodine uptake at post-therapy body scan may occur in benign or malignant conditions. The following benign pathological diagnosis may result in increased uptake:

- Presence of benign thyroid tissue (struma ovarii) $(1,2)$.

- Benign mucinous ovarian cystadenoma (3).

- Ovarian endometriosis cyst (4).

Pathology examination is the only way to differentiate between the diseases cited above, and to rule out malignant conditions, i.e., metastases of thyroid cancer cells to ovary and thyroid cancer originating from embryonic thyroid tissue in the ovary, which may also result in focal ovarian uptake.

Ghander and cols. (1) described a 24-year old woman, which seems to be the first case report of incidental diagnosis of struma ovarii in post-therapy ${ }^{131} \mathrm{I}$ whole-body scan following radioiodine remnant ablation for thyroid carcinoma. After levothyroxine withdrawal, that patient was treated with $3.7 \mathrm{GBq}$ of ${ }^{131} \mathrm{I}$. Whole-body scan showed thyroid bed uptake and right pelvic uptake; 18-FDG PET/CT scan did not identify any abnormal uptake. SPECT/CT was not performed. Pelvic ultrasound localized a right ovarian cyst, and surgical resection of the cyst revealed thyroid follicles corresponding to benign struma ovarii. Six months after resection of struma ovarii, and after 4 weeks of thyroid hormone withdrawal, stimulated serum thyroglobulin was undetectable $(<0.8 \mathrm{ng} / \mathrm{mL})$, and whole-body diagnostic scan was negative.

Macdonald and Armstrong (2) reported a 78-year old woman, referred for ${ }^{131} \mathrm{I}$ therapy following total thyroidectomy for papillary thyroid cancer. After levothyroxine withdrawal, she was treated with $5.55 \mathrm{GBq}$ ${ }^{131} \mathrm{I}$, and the post-therapy scan showed focal activity in the pelvis. SPECT-CT fusion examination localized lesion in the right ovary. She underwent laparoscopic oophorectomy, which revealed a benign follicular thyroid adenoma (struma ovarii). At 6-month follow-up, stimulated thyroglobulin was undetectable, and wholebody iodine scan was negative.

Utsunomiya and cols. (3) reported a 37-year old woman, who was referred for ablative radioiodine treatment after total thyroidectomy. After T4 withdrawal, 
the post-therapeutic ${ }^{131} \mathrm{I}$ scan showed an intense right pelvic hotspot. Ultrasound of the abdomen showed a 4-cm right ovarian cystic lesion. Laparoscopic right oophorectomy was performed, and histological examination revealed a benign mucinous cystadenoma of the ovary, without any coexisting thyroid tissue.

Lungo and cols. (4) reported a 28-year old woman who underwent total thyroidectomy for micro papillary carcinoma. Two and a half years later she required ${ }^{131} \mathrm{I}$ ablation for recurrent disease in a cervical lymph node. The post-therapeutic scan showed abnormal pelvic uptake. Histological diagnosis of the lesion was endometrial cyst without thyroid cells.

In our case, rhTSH was used as the patient prepared for ablation and therapy, in contrast to the first and second cases above, in which T4 withdrawal was used. Our patient's suppressed thyroglobulin level was $2.1 \mu \mathrm{g} / \mathrm{L}$, which would require further assessment and close follow-up. It is common for thyroglobulin level to continue to decline further, for a year or longer, and this value, at this time, is not diagnostic of residual disease.

In Ghander's report (1), PET scanning failed to identify benign struma ovarii, which was not a surprising finding, as many iodine-avid lesions, including cancers, are PET-negative. However, SPECT-CT, in our case, and in Macdonald and Armstrong's case (2) provided an excellent anatomically-correlated functional resolution.

Hybrid imaging employing SPECT and CT in a single instrument is now widely available. It has the advantage of being able to localize unusual physiological iodine accumulations within the anatomic context, in a single imaging session. Tharp and cols. (5) found that the use of this hybrid imaging combination contribut- ed to the immediate management of thyroid cancers in $25 \%$ of cases. It is usually not essential to have full diagnostic quality CT images to accurately place the uptake. Therefore, the beam current is much lower, and radiation dose incurred from CT is greatly reduced. Certainly, the combined images help to resolve unusual biodistribution of radioiodine on the post-therapy scan. SPECT/CT is expected to improve the diagnostic accuracy of radioiodine scanning and, therefore, to have a significant effect on thyroid cancer management.

Close teamwork is necessary between treating and imaging physicians to ensure the collection of the most relevant image sets.

Disclosure: no potential conflict of interest relevant to this article was reported.

\section{REFERENCES}

1. Ghander C, Lussato D, Conte Devolx B, Mundler O, Taïeb D. Incidental diagnosis of struma ovarii after thyroidectomy for thyroid cancer: functional imaging studies and follow-up. Gynecologic Oncology. 2006; 102:378-80.

2. MacdonaldW, Armstrong J. Benign struma ovarii in a patient with invasive papillary thyroid cancer: detection with I-131 SPECT-CT. Clin Nucl Med. 2007;32:380-2.

3. Utsunomiya D, Shiraishi S, Kawanaka K, Lwakatare F, Tomiguchi $\mathrm{S}$, Kido R. Struma ovarii coexisting with mucinous cystadenoma detected by radioactive iodine. Clin Nucl Med. 2003;28(9):725-7.

4. Lungo M, Tenenbaum F, Chaumerliac P, Vons $C$, Mirat A, Beuzen $F$, et al. Ovarian endometriosis cyst with iodine 131 uptake: first case of false positive in the follow up for differentiated thyroid carcinoma. Ann Endocrinol. 2000;61(2):147-50.

5. Tharp K, Israel O, Hausmann J, Bettman L, Martin WH, Daitzchman $\mathrm{M}$, et al. Impact of 131I-SPECT/CT images obtained with an integrated system in the follow-up of patients with thyroid carcinoma. Eur J Nucl Med Mol Imaging. 2004;31:1435-42. 